\title{
Effects of silver nanoparticles on neonatal testis development in mice
}

\author{
This article was published in the following Dove Press journal: \\ International Journal of Nanomedicine \\ 5 October 2015 \\ Number of times this article has been viewed
}

\author{
Xi-Feng Zhang ${ }^{1,2}$ \\ Sangiliyandi Gurunathan' \\ Jin-Hoi Kim' \\ 'Department of Animal Biotechnology, \\ Konkuk University, Seoul, Republic \\ of Korea; ${ }^{2}$ College of Biological and \\ Pharmaceutical Engineering, Wuhan \\ Polytechnic University, Wuhan, \\ People's Republic of China
}

Background: Metal nanoparticles (MNPs) play an important role in consumer products. An increasing use of MNPs has raised concerns about potential risks for human health. Therefore, in vivo tests of MNPs are urgently required. Using mice as a model animal, the aim of the present study was designed to investigate the effect of biologically synthesized silver nanoparticles (AgNPs) on spermatogenesis in neonatal mice.

Methods: AgNPs were synthesized using Bacillus funiculus. The prepared nanoparticles were characterized using various analytical techniques such as UV-visible spectroscopy, X-ray diffraction, Fourier transform-infrared spectroscopy, and transmission electron microscopy. The prepared AgNPs were used to investigate testis development in neonatal mice. Institute of Cancer Research neonatal male mice were used in all experiments and were treated with different doses $(0,1$, and $5 \mathrm{mg} / \mathrm{kg}$ ) of AgNPs five times (interval of 3 days from postnatal day [PND] 8-21) by abdominal subcutaneous injection.

Results: The results showed that the sperm abnormalities such as quality and quantity were significantly increased by the synthesized AgNPs. The diameter of the convoluted tubules shrank significantly in mice treated with AgNPs on PND28 and PND42. The results of reverse transcription-quantitative polymerase chain reaction indicated that the E1flay, Gsta4, and FdxI genes were up-regulated, and the Amh, Cx43, and Claudin-11 genes were down-regulated in response to AgNPs exposure on PND28; however, these genes recovered at PND60. AgNPs had no effect on the recombination levels of chromosomes in germ cells.

Conclusion: These results demonstrated the adverse effects of AgNPs on the male reproductive tract, particularly spermatogenesis and the quality of sperm. This study suggests that the development of nanomaterials should be safer and non-toxic to the living organisms and the potential reprotoxicity of AgNPs should be investigated more carefully.

Keywords: silver nanoparticles, male mouse, sperm, gene expression, testis development

\section{Introduction}

Nanotechnology is the use of a single atom for molecular manufacturing in material science and technology, evaluation of the structure, properties, and application of nanometer-sized materials (range: $1-100 \mathrm{~nm}$ ). Based on material control and the transmission and transformation in the creation of new materials and devices, nanotechnology makes full use of the unique properties of these materials, and explores new phenomena and the laws of matter motion at the nanoscale. ${ }^{1}$ Nanomaterials and nanotechnology have been applied to varying degrees in the development of new materials, including in the fields of medicine, aerospace, the environment, energy, biotechnology, agriculture, and others. ${ }^{2-4}$ Nanotechnology has also been used in the high-speed development of semiconductor chips, cancer treatment, new materials, and biomolecular optical tracking applications. Among the diverse nanomaterials available, silver nanoparticles (AgNPs)
Correspondence: Sangiliyandi

Gurunathan; Jin-Hoi Kim

Department of Animal Biotechnology,

Konkuk University, I Hwayang-dong,

Kwangjin-gu, Seoul I43-70I, Republic of Korea

Tel +82 24503687

Fax +82 25444645

Email gsangiliyandi@yahoo.com;

jhkim54l@konkuk.ac.kr
International Journal of Nanomedicine 2015:10 6243-6256 
are the most commonly engineered nanomaterials used in various areas of research. Due to their unique properties such as optical, magnetic, and mechanical properties, the catalytic performance and antibacterial effects of AgNPs have been widely used in the fields of photonics, pesticide detection, bio-sensing, antimicrobial applications, photocatalysts, and electronics, among others..$^{5-8}$ Their well-known antimicrobial properties are used in the development of AgNPs-based products, including antiseptic sprays, food storage containers, bandages, and catheters. Along with effective broad-spectrum biocides against a variety of drug-resistant bacteria, AgNPs are potential candidates for use in pharmaceutical products and medical devices to prevent the transmission of drug-resistant pathogens in various clinical environments. ${ }^{9,10}$ AgNPs can interact with the disulfide bonds of glycoproteins/proteins in microorganisms such as viruses and bacteria, and can change the three-dimensional structure of proteins to consequently inhibit the function of microorganisms. ${ }^{9}$ AgNPs have also attracted increased attention for anticancer treatments due to their therapeutic applications. ${ }^{11}$

As a result of the wide application of AgNPs, they are now a part of daily life and are commonly found in consumer products as well as in medical devices. However, the safety of AgNPs is a growing concern, as nanoparticles can be inhaled by domestic users and patients exposed to medical products containing AgNPs. Additionally, there are several possible ways in which patients can be exposed to AgNPs, such as dermal contact, oral administration, inhalation, and blood circulation for the reason that AgNPs contained in medicinal uses, and then AgNPs could be released into human body during use, representing a potential risk of exposure and subsequent health concerns, especially in relation to their distribution, bioaccumulation, and bioavailability in humans. ${ }^{12-14}$ Studies have been carried out to evaluate the cytotoxicity and genotoxicity of AgNPs in cells, mice, fish, and spermatozoa. ${ }^{15,16}$ It is widely accepted that a high concentration of AgNPs can cause severe morphological abnormalities, inhibition of cell proliferation, increased apoptosis in human cells, and inhibition of new DNA synthesis. ${ }^{17,18}$ Following the subcutaneous injection of AgNPs in rats, they were found to be distributed in the kidneys, liver, spleen, lungs, and brain, and caused blood-brain barrier damage and neuronal degeneration. ${ }^{19}$ Furthermore, AgNPs can induce inflammatory responses such as inflammatory cell infiltration and chronic alveolar inflammation, and can further induce the impairment and dysfunction of brain cells and immunotoxicity. ${ }^{20,21}$ AgNPs were also found to induce hepatotoxicity, in which the liver exhibited lymphocytic infiltration, and promoted the expression of genes associated with apoptosis and inflammation. ${ }^{22}$
In vitro studies showed that AgNPs can damage the mitochondria, and increase reactive oxygen species production and apoptosis in a 533 -dependent process involving reactive oxygen species and the c-Jun N-terminal kinase cascade, or via the IKK/NF- $\kappa$ B pathway. ${ }^{23-25}$

Thus, although the unique properties of AgNPs have led to their use in a broad range of applications, more attention has been paid to the production of AgNPs rather than to their applications. ${ }^{26}$ Indeed, various methods for the synthesis of AgNPs have been reported in the literature. Physical, chemical, and biological methods are the main techniques used for the synthesis of AgNPs. Chemical methods produce toxic waste and require the use of various toxic materials, including hydrazine, citrate, borohydride, and other organic compounds, which can affect human health, living organisms, and the environment. ${ }^{27,28}$ Physical methods result in the production of low yields of AgNPs. Biological methods, otherwise known as the green synthesis of AgNPs, involve molecules produced by living organisms such as plants, microorganisms, and non-toxic substances. ${ }^{29-33}$ Recently, the use of numerous microorganisms in the synthesis of AgNPs has been reported, including bacteria such as Sphingomonas, Bacillus licheniformis, Brevibacterium casei, and Escherichia coli. ${ }^{32-34}$

Considering this background, the primary aim of this study was to develop a novel method for the synthesis of AgNPs using a biological system. The secondary aim of this study was to evaluate the toxicity of these biologically prepared AgNPs in Leydig cells (LCs) and Sertoli cells (SCs) from the mouse testis and in neonatal mice. LCs and SCs are two important cells in testis for synthesis and secretion of testosterone and the main somatic cells of testis that are important for spermatogenesis in testis. Finally, evaluation of the toxicity of AgNPs in testis development and the time course effects of these AgNPs were evaluated at postnatal day PND28, PND42, PND60, and PND100 in mice.

\section{Materials and methods Synthesis of AgNPs}

Luria-Bertani medium was prepared for the culture of Bacillus funiculus, which was grown in a $500-\mathrm{mL}$ Erlenmeyer flask containing $100 \mathrm{~mL}$ Luria-Bertani broth, and the flasks were incubated for 24 hours in a shaker at $150 \mathrm{rpm}$ and $37^{\circ} \mathrm{C}$. Following the incubation period, the culture was collected and centrifuged at 10,000 rpm and the supernatant was used for the synthesis of AgNPs. $\mathrm{AgNO}_{3}$ solution (Sigma-Aldrich Co., St Louis, MO, USA; 99.9\% pure) was added at a concentration of $5 \mathrm{mM}$, and then incubated for 6-12 hours at $40^{\circ} \mathrm{C}$. The extracellular synthesis of AgNPs 
was monitored by visual inspection of the test tubes for a change in the color of the culture medium. Formation of a brown color indicated the successful production of AgNPs. Synthesis of AgNPs was carried out according to a previously described method..$^{35}$

\section{Characterization of AgNPs}

An AgNPs solution ( $1 \mathrm{mg} / \mathrm{mL}$ ) was prepared in our laboratory. AgNPs were characterized as previously described. ${ }^{35}$ Ultraviolet-visible (UV-vis) spectra were recorded using an OPTIZEN spectrophotometer (Mecasys, Seoul, South Korea). X-ray diffraction (XRD) analyses were performed using an X-ray diffractometer (Bruker D8 DISCOVER; Bruker AXS GmBH, Karlsruhe, Germany). The high-resolution XRD measurements were performed at $3 \mathrm{~kW}$ with the $\mathrm{Cu}$ target using a scintillation counter $(\lambda=1.5406 \AA)$ at $40 \mathrm{kV}$ and $40 \mathrm{~mA}$, and were recorded in the range of $2 \theta=5^{\circ}-80^{\circ}$. Further characterization of the surface changes and composition of AgNPs was performed by Fourier transform-infrared spectroscopy (FT-IR; Perkin Elmer Spectroscope GX; PerkinElmer, Waltham, MA, USA). Transmission electron microscopy (TEM; Hitachi H-7500, Seoul National University, Seoul, South Korea) and software Image-Pro Plus 5.1 were used to determine the size and morphology of the AgNPs; TEM images of the biologically synthesized AgNPs were obtained at an accelerating voltage of $300 \mathrm{kV}$.

\section{Cell culture and exposure of cells to AgNPs}

The TM3 (LCs, KCLB No 21714) and TM4 (SCs, KCLB No 21715) cell lines, collected from the mouse testis, were cultured in Dulbecco's Modified Eagle's Medium (Hyclone, Waltham, MA, USA) supplemented with fetal bovine serum $(10 \%)$ and antibiotics $(100 \mathrm{U} / \mathrm{mL}$ penicillin and $100 \mu \mathrm{g} / \mathrm{mL}$ streptomycin) at $37^{\circ} \mathrm{C}$ in a $5 \% \mathrm{CO}_{2}$ atmosphere. The cells were seeded onto plates at a density of $1 \times 10^{4}$ cells per well and incubated for 24 hours before the experiments. The cells were washed with phosphate-buffered saline $(\mathrm{pH} 7.4)$ and incubated in fresh medium containing different concentrations of AgNPs dissolved in water.

\section{Animals and experimental design}

All experiments were conducted following approval from the Institutional Animal Care and Use Committee at Konkuk University (IACUC Approval No KU11035), Seoul, Korea. Institute of Cancer Research mice were housed under temperature-controlled $\left(21^{\circ} \mathrm{C}-22^{\circ} \mathrm{C}\right)$ and light-controlled (12/12-hour light-dark cycle) conditions. Eight-day-old
(PND8) male mice were used in this study. The mice were administered the AgNPs suspension via an abdominal subcutaneous injection in five doses over 13 days (from PND8 to PND21) at 1 and $5 \mathrm{mg} / \mathrm{kg}$ per dose. The vehicle controls received water. Reproductive toxicology assessments were conducted at PND28, PND42, PND63, and PND100.

\section{Cytotoxicity of AgNPs}

The 3(4-5-dimethylthiazol-2-yl)-2,5-diphenyltetrazolium bromide (MTT) assay was used to investigate mitochondrial function, as described by Zhang et al. ${ }^{36}$ In brief, $1 \times 10^{4}$ cells were seeded in a 96-well plate and exposed to different concentrations of AgNPs for 24 hours. After the exposure was completed, the culture medium was removed from each well, replaced with $100 \mu \mathrm{L}$ of new medium containing MTT, incubated for 3 hours at $37^{\circ} \mathrm{C}$, and the absorbance was measured at $450 \mathrm{~nm}$ using a microplate reader (PerkinElmer). The lactate dehydrogenase (LDH) leakage assay was carried out using an LDH cytotoxicity assay kit (LDH Assay Kit, Abcam, Cambridge, MA, USA). LDH activity was determined in the spent medium by measuring the absorbance at $490 \mathrm{~nm}$ using a Multiskan FC multiplate reader.

\section{Histological examination of the testis}

Mouse testes were collected at PND28, PND42, PND60, and PND100 and fixed in 10\% neutral formalin for histological examination. Each testis was sliced into $5 \mu \mathrm{m}$ sections, with representative sections taken every ten sections for evaluation using 4',6-diamidino-2-phenylindole staining. A total of three samples from three mice were obtained from each group. Slices were imaged under a light microscope (Olympus BX51; Olympus Corporation, Tokyo, Japan).

\section{RNA isolation and reverse transcription- quantitative polymerase chain reaction}

Total RNA was isolated from the testes using an RNeasy Micro Kit (Qiagen, Hilden, Germany) according to the manufacturer's instructions. cDNA was synthesized using a PrimeScript ${ }^{\mathrm{TM}}$ RT reagent Kit (TaKaRa, Shiga, Japan) according to the manufacturer's instructions. The reaction system contained 25 pmol OligodT primer, 50 pmol random primers, appended RNA, and $5 \times$ PrimerScript ${ }^{\mathrm{TM}}$ Buffer up to a $20 \mu \mathrm{L}$ final volume. Reverse transcriptase quantitative polymerase chain reaction (RT-PCRs) were carried out to quantify gene expression levels with SYBR Premix Ex Taq ${ }^{\mathrm{TM}}$ Kit (TaKaRa) in a Light Cycler 480 II (Roche, Mannheim, Germany). Relative RNA equivalents for each sample were obtained by standardization with $\beta$-actin. The gene primer sets are shown in Table 1. 
Table I Primers used for RT-PCR

\begin{tabular}{|c|c|c|}
\hline Genes & Sequences of primers & GenBank \\
\hline \multirow[t]{2}{*}{ GAPDH } & F: 5'-AGGTCGGTGTGAACGGATTTG-3' & NC_000072.6 \\
\hline & R: 5'-TGTAGACCATGTAGTTGAGGTCA-3' & \\
\hline \multirow[t]{2}{*}{$D D \times 3 Y$} & F: 5'-GACAGATCAGATGAAGATGACTGGT-3' & NC_000087.7 \\
\hline & R: 5'-GTGAGGAGGACAATTATTTCCAGTT-3' & \\
\hline \multirow[t]{2}{*}{ EIFIAY } & F: 5'-TCGTAGCCCCACCAATATGA-3' & NC_000086 \\
\hline & R: 5'-GCGAGAGCTTGTGTTCAAGG-3' & \\
\hline \multirow[t]{2}{*}{$E b p$} & F: 5'-CTAATTGTGATCACGTGGCTGTT-3' & NC_000086.7 \\
\hline & R: 5'-GATATATCGGCTATCTCCCTTGGA-3' & \\
\hline \multirow[t]{2}{*}{$F d x I$} & F: 5'-ACTGCCATCTCTCCGTGGAC-3' & NC_000075.6 \\
\hline & R: 5'-AATCACAACATCTAGCAGAGAGTCG-3' & \\
\hline \multirow[t]{2}{*}{ Cypl7al } & F: 5'-TGACCAGAAACTGGAGAAGATGATA-3' & NC_000085.6 \\
\hline & R: 5'-CCTTGTTCTCAAAAGAGATGTTGAA-3' & \\
\hline \multirow[t]{2}{*}{ Cyp/9al } & F: 5'-GGAAGTGCCTGCAACTACTACAATA-3' & NC_000075.6 \\
\hline & R: 5'-TTGTTGTTAAATATGATGCCGTTCT-3' & \\
\hline \multirow[t]{2}{*}{ GpxI } & F: 5'-GACTACACCGAGATGAACGATCTG-3' & NC_000075.6 \\
\hline & R: 5'-ATTCACTTCGCACTTCTCAAACAA-3' & \\
\hline \multirow[t]{2}{*}{ Gsta4 } & F: 5'-AACTTGTATGGGAAGGACCTGAAG-3' & NC_000075.6 \\
\hline & R: 5'-AACACTGGGAAGTAACGGGTTTTA-3' & \\
\hline \multirow[t]{2}{*}{$\operatorname{Prd} \times 2$} & F: 5'-AAAGTCGGCTCCTGACTTCAC-3' & NC_000074.6 \\
\hline & R: 5'-AGCCTAGCTTTCGGAAGTCCTC-3' & \\
\hline \multirow[t]{2}{*}{ StAR } & F: 5'-AGAGCTCAACTGGAGAGCACTG-3' & NC_000074.6 \\
\hline & R: 5'-AGCCTTCCTGGTTGTTGAGTATG-3' & \\
\hline \multirow[t]{2}{*}{ Zo-I } & F: 5'-CTCTGGTGGAAGAGATAATCCTCA-3' & NC_000073.6 \\
\hline & R: 5'-GTTTTTCCCACTCTTCCTTAGCTG-3' & \\
\hline \multirow[t]{2}{*}{ Claudin-II } & F: 5'-GTCACAACGTCCACCAATGACT-3' & NC_000069.6 \\
\hline & R: 5'-AGAACTGTCAACAGCAGCAAGAT-3' & \\
\hline \multirow[t]{2}{*}{ Amh } & F: 5'-GGATGACTCCCACCСTGGTG-3' & NC_000076.6 \\
\hline & R: 5'-GGGAAAGGCATGGTGTCCAG-3' & \\
\hline \multirow[t]{2}{*}{ Occludin } & F: 5'-ATGATTATCGTGGCTTTTGCTTTA-3' & NC_000079.6 \\
\hline & R: 5'-ACTGTCAACTCTTTCCGCATAGTC-3' & \\
\hline \multirow[t]{2}{*}{$C x 43$} & F: 5'-TGTGGGCAAGACACGAATATG-3' & NC_000076.6 \\
\hline & R: 5'-GACAAGGTCCAAGCCTACTCCC-3' & \\
\hline \multirow[t]{2}{*}{ MlhI } & F: 5'-GGCGTTTGTAGCAGGAGTTATTC-3' & NC_000075.6 \\
\hline & R: 5'-CCATTGTCTTGGATCTGAATTAGC-3' & \\
\hline \multirow[t]{2}{*}{$\operatorname{Rad54}$} & F: 5'-AGGAAACCAGAAGACAGATCATCA-3' & NC_000070.6 \\
\hline & R: 5'-TGTTGACTGCTATCCAGACAAGGT-3' & \\
\hline
\end{tabular}

Abbreviations: F, forward; $R$, reverse.

\section{Analyses of MLHI signals}

Analyses of MLH1 signals were performed according to a published protocol. ${ }^{37}$ The antibodies against SCP3 (ab15093; Abcam) and MLH1 (ab1295, Abcam) were added to analyze recombination in the same cells. Images of the SCP3 fragments and MLH1 foci were captured using the Image Pro-Plus 5.1 software (Media Cybernetics Inc; Bethesda, MD, USA). In addition, pachytene cell images were captured if clear MLH1 foci were present. Depending on the SCP3 staining results, more than 100 meiotic cells in pachytene were randomly selected for analysis. MLH1 signals were scored only if they were distinct and localized on SCs in the subset and the pachytene cells exhibited normal synapsis.
Scoring was conducted by two independent observers who were blinded with respect to the group.

\section{Sperm analysis}

Following removal of the epididymis, the caudal part was cut and the tubules were dispersed in Medium199 (supplemented with $0.5 \%$ bovine serum albumin) in a $35 \mathrm{~mm}$ plastic petri dish for incubation. The petri dish was placed in an incubator at $37^{\circ} \mathrm{C}$ for 10 minutes to allow the sperm to disperse. The semen sample was smeared on a slide, fixed in $10 \%$ neutral buffered formalin, and stained with $1 \%$ eosin solution. The morphology of more than 500 sperms from each sample was examined under a microscope. 


\section{Statistical methods}

Independent experiments were repeated at least three times, and data are presented as mean \pm standard deviation (SD) for all duplicates within an individual experiment. Data were analyzed using the Student $t$-test or one-way analysis of variance followed by the Tukey test for multiple comparisons to determine the differences between groups (denoted by an asterisk or different letters) using the Graph-Pad Prism analysis software.

\section{Results and discussion Characterization of AgNPs using UV-vis spectroscopy}

Nanoparticles are able to penetrate through biological barriers into reproductive tissues, and should therefore have an impact on sperm vitality and function as well as on embryo development. ${ }^{38}$ In particular, smaller sized nanoparticles can more easily penetrate the tissues than larger nanoparticles, and are therefore expected to cause several problems. In order to produce controlled size of particles address this issue, we prepared AgNPs using a biological system with B. funiculus, and the prepared AgNPs were characterized using various analytical techniques, including UV-vis spectroscopy. First, the synthesized AgNPs were characterized by optical absorption analysis. The UV spectra of the synthesized AgNPs were analyzed and the synthesized AgNPs showed maximum excitation at $412 \mathrm{~nm}$ (Figure 1). In the UV-vis spectrum, a strong, broad peak with 0.13 absorbance was observed at $412 \mathrm{~nm}$, indicating the formation of AgNPs. The specific features of this peak can be attributed to surface plasmons, and have been well documented for various metal nanoparticles (MNPs) with sizes ranging from 2 to $100 \mathrm{~nm} .{ }^{39}$

\section{Characterization of AgNPs using XRD}

The crystalline natures of the synthesized AgNPs were characterized using XRD. The XRD pattern obtained for

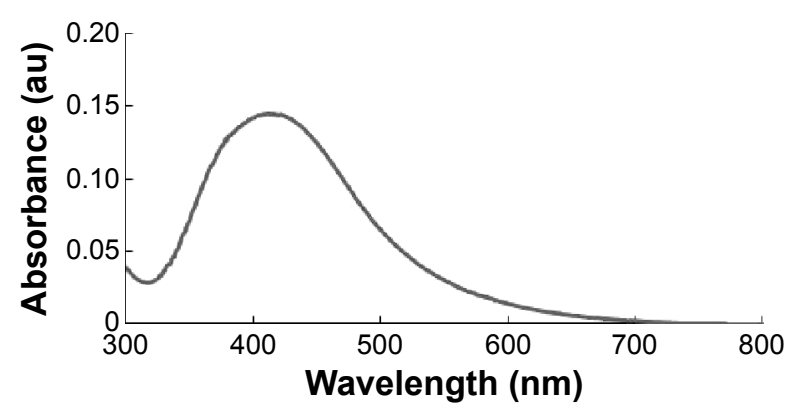

Figure I The absorption spectrum of silver nanoparticles synthesized in the Bacillus funiculus culture supernatant.

Notes: The absorption spectrum of silver nanoparticles exhibited a strong, broad peak at $412 \mathrm{~nm}$, which was assigned to the surface plasmon resonance of the particles. Abbreviation: au, arbitrary unit. the AgNPs showed four intense peaks in the whole spectrum of $2 \theta$ values ranging from 20 to 80 . Figure 2 shows the XRD patterns obtained from the AgNPs synthesized by B. funiculus. The presence of intense peaks of nanoparticles (111), (200), and (220) appeared that reflect the crystalline silver face-centered cubic phase. This is similar to the standard XRD patterns for Agare [Joint Committee on Powder Diffraction Standards file no: 04-0783 for Ag]. The XRD pattern thus clearly showed that the AgNPs formed by the reduction of $\mathrm{Ag}^{+}$ions by $B$. funiculus were crystalline in nature. Several previous studies reported that bacteria could reduce silver ions, including $B$. licheniformis, ${ }^{33} \mathrm{E}$. coli, ${ }^{35}$ and B. casei. ${ }^{34}$ In addition, one additional and yet unassigned peak was also observed in the vicinity of the characteristic peaks of silver $\left(29^{\circ}\right)$. These sharp Bragg peaks might have resulted from some bioorganic compound/protein(s) present in B. funiculus. The intensity of the Bragg reflections suggests strong $X$-ray scattering centers in the crystalline phase and could have possibly arisen from proteins present in the nanoparticles during their synthesis. ${ }^{35,40}$

\section{Characterization of AgNPs using FT-IR}

FT-IR measurements were performed to identify the biomolecules responsible for the capping and efficient stabilization of the MNPs synthesized by B. funiculus. ${ }^{34}$

Figure 3 shows the FT-IR spectra of the synthesized AgNPs. Representative spectra of the obtained nanoparticles manifested absorption peaks located at approximately $3,455.27 \mathrm{~cm}^{-1}$ $(-\mathrm{NH}), 1,628.15 \mathrm{~cm}^{-1}$ (amide I), and 1,401.54 $\mathrm{cm}^{-1}(\mathrm{C}=\mathrm{O})$. The peak at $1,401.54 \mathrm{~cm}^{-1}$ represented the asymmetrical and symmetrical vibrations of carboxylate ions. The FT-IR spectra results indicated that the peak at $3,455.27 \mathrm{~cm}^{-1}(-\mathrm{NH})$ was responsible for the binding of AgNPs (Figure 3). ${ }^{41}$

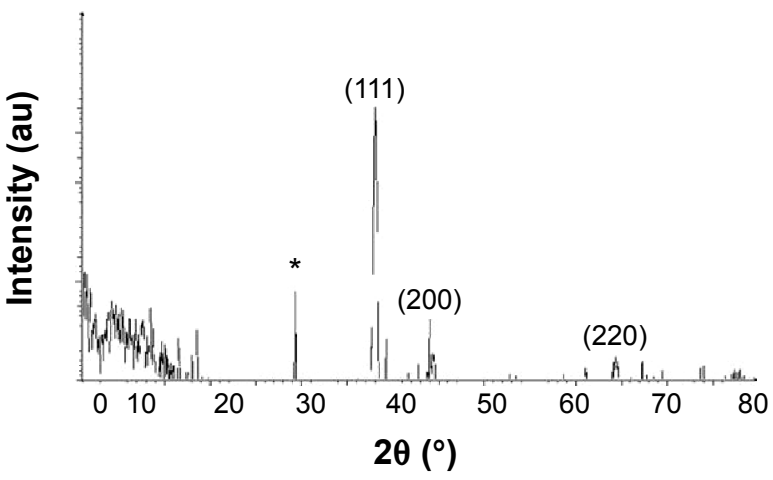

Figure 2 X-ray diffraction pattern of the silver nanoparticles.

Notes: Silver nanoparticles were synthesized from I mM silver nitrate-treated Bacillus funiculus cells at $37^{\circ} \mathrm{C}$. The samples were harvested at 24 hours, sonicated, and air dried, and the X-ray diffraction pattern was observed. *Indicates the nonspecific peaks due to residues from culture supernatant.

Abbreviation: au, arbitrary unit. 


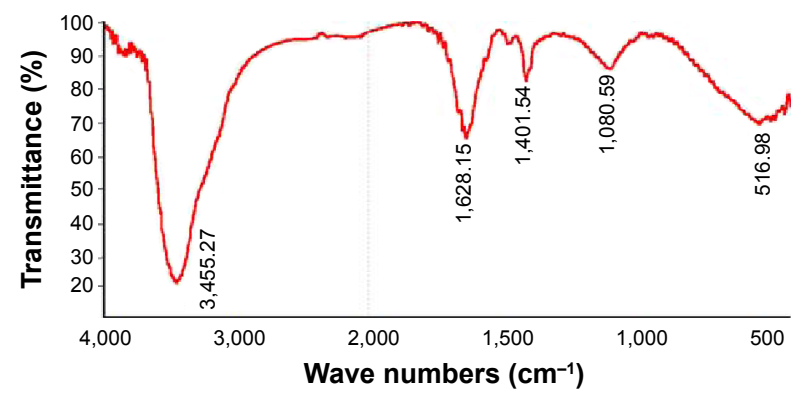

Figure 3 Fourier transform-infrared spectra of the silver nanoparticles synthesized in the Bacillus funiculus culture supernatant.

The broad spectrum of the $3,455 \mathrm{~cm}^{-1}$ FT-IR peak resulted from the strong stretching vibrations of the hydroxyl $(\mathrm{OH})$ functional group. The presence of proteins found in the culture supernatant of bacteria could be responsible for the reduction of metal ions to their corresponding MNPs. It is also possible that proteins/enzymes play a role in the reduction of metal ions by the oxidation of benzaldehyde (an aldehyde group) to carboxylic acids. ${ }^{42}$ The peak at $3,455 \mathrm{~cm}^{-1}$ resulted from stretching of the $\mathrm{N}-\mathrm{H}$ bond of amino groups, and is indicative of bonded hydroxyl $(-\mathrm{OH})$ groups. The peak at $1,401 \mathrm{~cm}^{-1}$ indicates the fingerprint region of $\mathrm{CO}, \mathrm{C}-\mathrm{O}$, and $\mathrm{O}-\mathrm{H}$ groups, which exist as functional groups in the bacterial supernatant. The absorption peaks at $1,401 \mathrm{~cm}^{-1}$ could be attributed to the presence of $\mathrm{C}-\mathrm{O}$ stretching in carboxyl groups coupled to the amide linkage in amide I. The band at $1,628 \mathrm{~cm}^{-1}$ is a characteristic of amide I, and arises as a result of the $\mathrm{N}-\mathrm{H}$ stretching modes of vibration in the amide linkage. The intense band at $1,080 \mathrm{~cm}^{-1}$ can be assigned to the $\mathrm{C}-\mathrm{N}$ stretching vibrations of aliphatic amines. The FT-IR

A

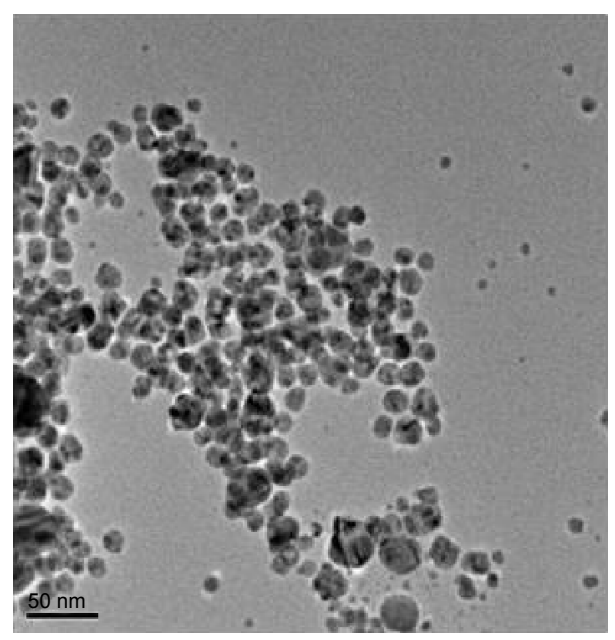

study of AgNPs indicated that the carboxyl $(-\mathrm{C}=\mathrm{O})$, hydroxyl $(-\mathrm{OH})$, and amine $(\mathrm{N}-\mathrm{H})$ groups of the culture supernatant from bacteria are mainly involved in the reduction of $\mathrm{Ag}^{+}$ to $\mathrm{Ag}^{0}$ nanoparticles.

\section{Surface morphology and size analysis of AgNPs}

The structures of AgNPs were analyzed using TEM, and are shown in Figure 4A. The particles were significantly spherical in shape. The average diameter was calculated by measuring the particles in random fields of the TEM field of view and from images showing the general morphology of the nanoparticles. Figure 4B shows that the AgNPs were between 10 and $40 \mathrm{~nm}$ in size, with an average size of $15 \mathrm{~nm}$.

\section{Cytotoxic effects of AgNPs in LCs and $\mathrm{SCs}$}

AgNPs toxicity was shown in various cell types including Hepg2 cell, human lung cell, and brain neural cells. ${ }^{43-45}$ In addition, AgNPs have a broad tissue distribution in vivo, the liver is the major target organ, followed by the spleen, brain, lung, liver, kidney, and testis. ${ }^{46-50}$ In this study, we first aimed to investigate whether AgNPs have an impact on LCs and SCs of testis. To assess the toxic potential of AgNPs, MTT and LDH assays were performed. Figure $5 \mathrm{~A}$ and $\mathrm{B}$ shows the viability of LCs and SCs, respectively. The results clearly demonstrated that cell viability was directly proportional to the concentration of AgNPs applied to the cells and cell death was observed in a concentration-dependent manner. Cell death gradually increased according to the concentration of AgNPs

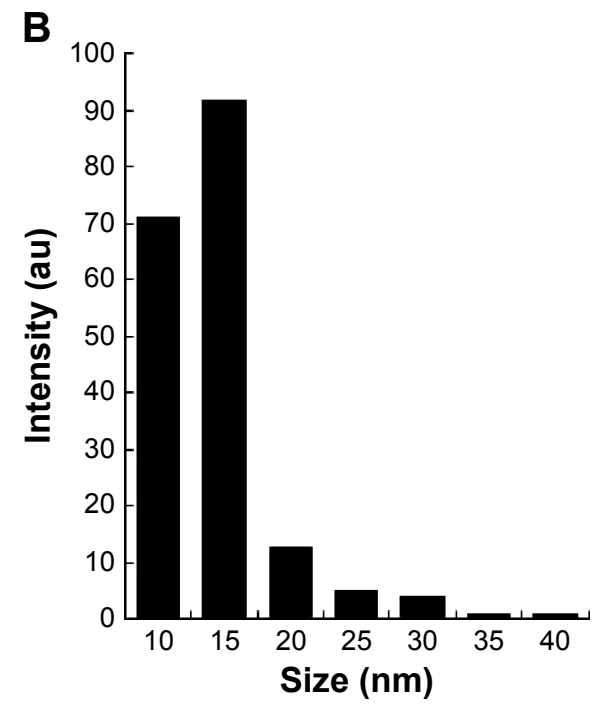

Figure 4 Surface and shape morphology of silver nanoparticles using transmission electron microscopy.

Notes: (A) Transmission electron 573 microscopy image and (B) the size distribution of silver nanoparticles.

Abbreviation: au, arbitrary unit. 
A

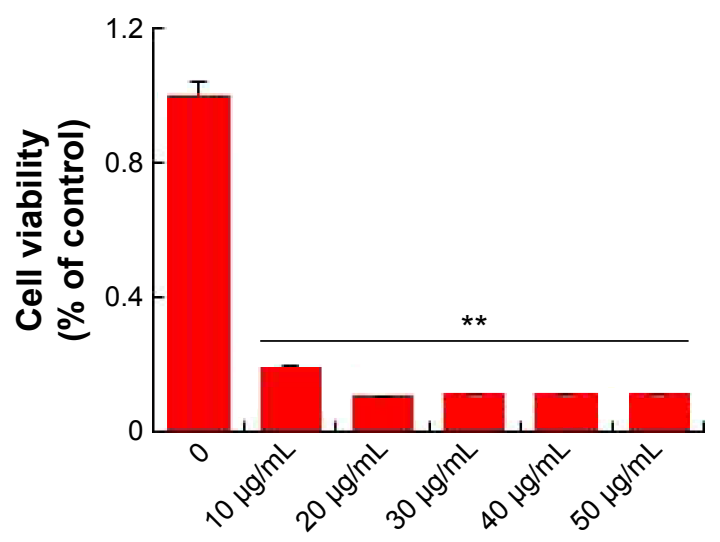

C

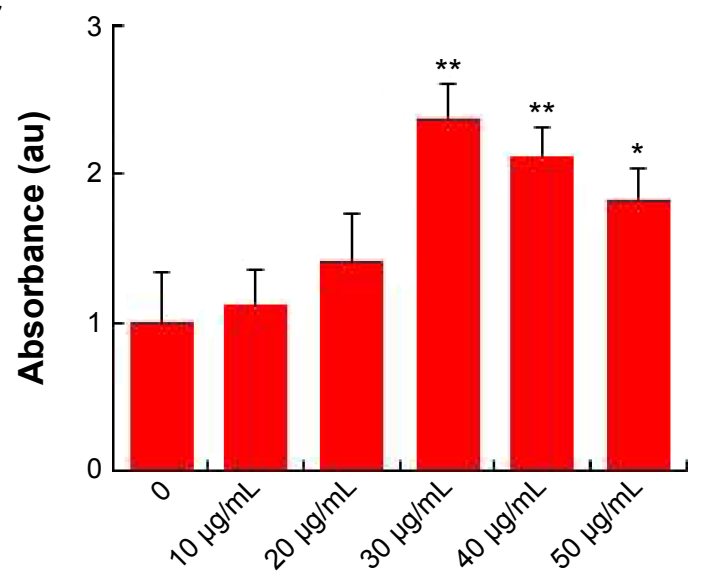

B

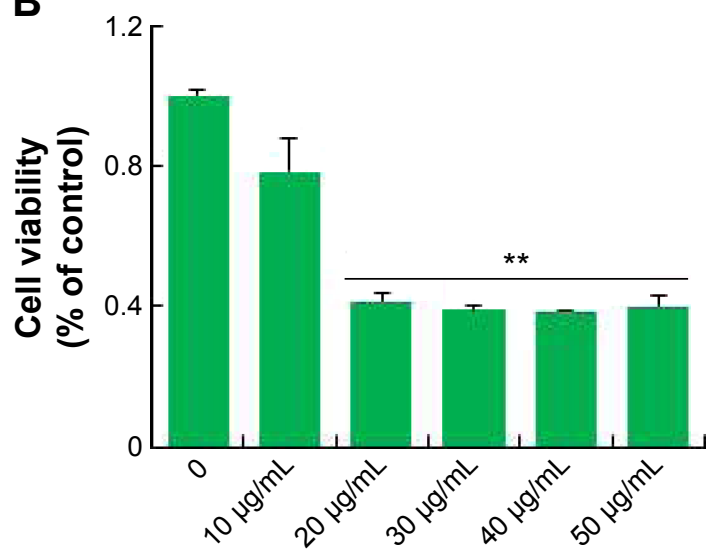

D

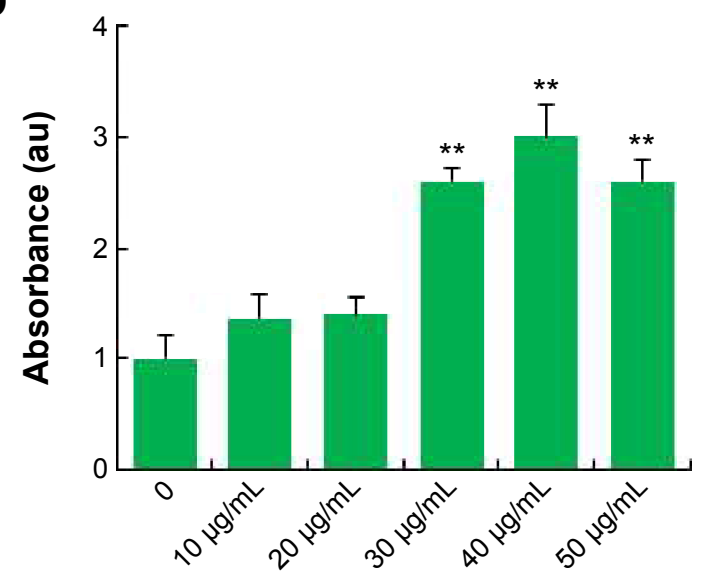

Figure 5 Cytotoxic effects of silver nanoparticles in Leydig cells and Sertoli cells.

Notes: Leydig cells and Sertoli cells were treated with various concentrations of silver nanoparticles for 24 hours, and cytotoxicity was determined using 3(4-5-dimethylthiazol-2-yl)2,5-diphenyltetrazolium bromide (MTT) and lactate dehydrogenase (LDH) assays. The results represent the means of three independent experiments, and the error bars show the standard errors of the means. The cytotoxicity of silver nanoparticles-treated groups was significantly different from that of the control group, as determined by the Student's $t$-test $(P<0.05)$. (A) The MTT assays of Leydig cells. (B) The MTT assays of Sertoli cells. (C) LDH assays of Leydig cells. (D) LDH assays of Sertoli cells. $* P<0.05$, $* * P<0.0$ I. Abbreviation: au, arbitrary unit.

over 24 hours. In addition, the cells were treated with various concentrations of AgNPs for 24 hours, and the LDH leakage assay, a conventional cell viability test method, should be employed with caution when assessing cytotoxicity of AgNPs. $\mathrm{LDH}$ is released after cell membrane damage. As shown in Figure 5C and D, increasing concentrations of AgNPs led to higher levels of membrane leakage, which suggested that LDH leakage was dose dependent. Thus, these results suggest that AgNPs can induce a cytotoxic effect in LCs and SCs.

\section{Effects of AgNPs on mice}

As shown in Figure 6A, two different doses of AgNPs were injected into mice and the effects of these AgNPs on body weight, testis weight, and sperm were monitored. As shown in Figure 6B, the average testis weight/body weight in AgNPs-treated mice were not significantly different from that in control mice at PND28, PND60, and PND100.
The average testis weight/body weight was significantly reduced at PND42 only in the $5 \mathrm{mg} / \mathrm{kg}$-treated group. As shown in Figure 6C and D, the diameter of the convoluted tubules in mice treated with AgNPs shrunk significantly at PND28 and PND42 compared with the control, especially at PND42 $(P<0.05$; Figure 6D). Sperm quality was also evaluated in this study. There was a significant increase in the rate of abnormal sperm following AgNPs treatment at PND42, PND60, and PND100 compared with the control $(P<0.05$ or $P<0.01$; Figure $6 \mathrm{E})$. In addition, the concentration of sperm was significantly reduced in the $5 \mathrm{mg} / \mathrm{kg}$-treated group at PND100 $(P<0.01$; Figure 6F). Braydich-Stolleet et al reported that AgNPs decreased the proliferation of spermatogonial stem cells. ${ }^{51,52}$ To support these in vitro data, intravenous injection of AgNPs into mice showed a reduced sperm count and an increase in sperm DNA damage. ${ }^{53}$ Taken together, the results from this study indicated that AgNPs 
A

Dosing

(1 $\mathrm{mg} / \mathrm{kg}, 5 \mathrm{mg} / \mathrm{kg}$ each)<smiles>C#CC#C</smiles>
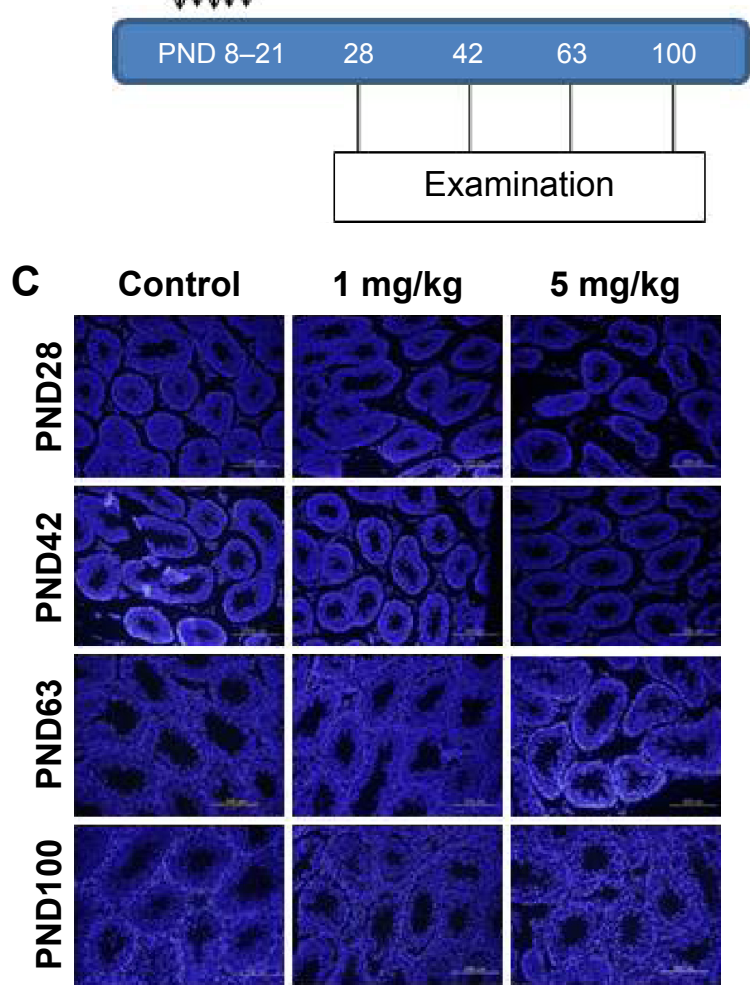

E

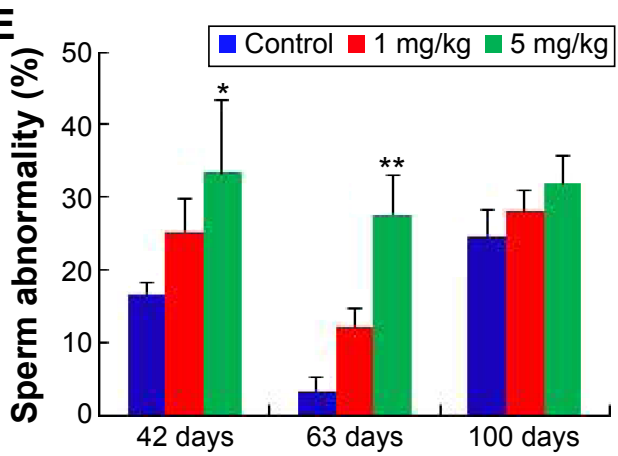

B Control $\square 1 \mathrm{mg} / \mathrm{kg} \square 5 \mathrm{mg} / \mathrm{kg}$

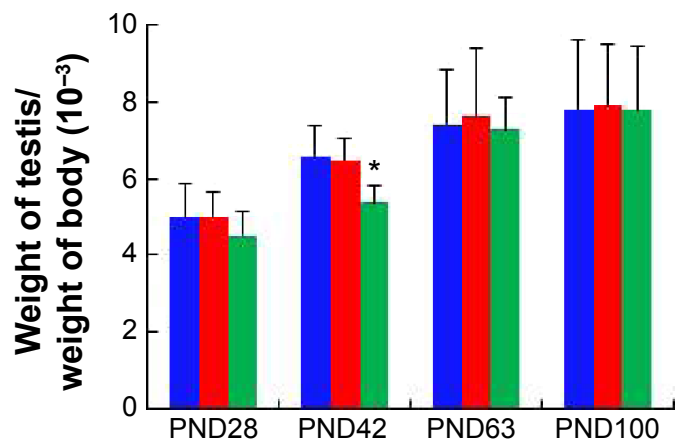

D

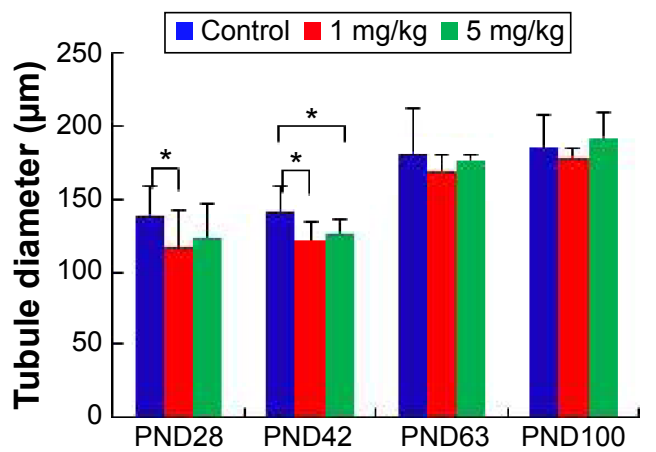

$\mathbf{F}$

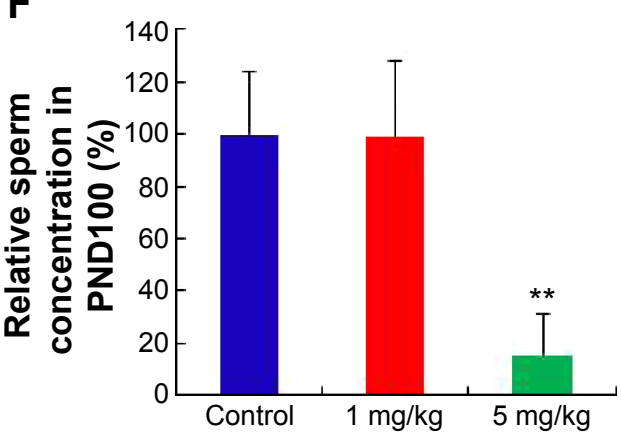

Figure 6 Treatment of neonatal male mice with silver nanoparticles.

Notes: (A) Figure shows five doses administered over 13 days at $5 \mathrm{mg} / \mathrm{kg}$ per dose. Reproductive toxicity was assessed at postnatal day PND28, PND42, PND60, and PND 100. Arrows indicate the injection of AgNPs five times from PND8 to PND2I. (B) The ratio of testis weight/body weight of mice injected with silver nanoparticles or water showed no statistically significant differences, with the exception of the $5 \mathrm{mg} / \mathrm{kg}$-treated group at PND42. (C) Histological examination of the testis using $4^{\prime}, 6-$ diamidino-2-phenylindole (DAPI). (D) The diameter of the convoluted tubules in silver nanoparticles-treated mice at PND28 and PND42 compared with the control. The diameter of the convoluted tubules in the two treatment groups shrank markedly in comparison to the control at PND42 ( $<<0.05)$. (E) Percentage of abnormal sperm from morphological examination. There was an obvious increase in the rate of abnormal sperm in the silver nanoparticles-treated groups. (F) The concentration of sperm at PNDI00 was significantly reduced in the $5 \mathrm{mg} / \mathrm{kg}$-treated group $(P<0.01)$. $* P<0.05, * * P<0.01$.

Abbreviation: PND, postnatal day.

could cause adverse effects on the male reproductive tract, particularly with respect to spermatogenesis.

\section{Recombination aberrations verified by metaphase I analysis}

In the seminiferous tubules, spermatozoa are generated and are differentiated into sperm cells through meiosis.
Exposure to harmful substances in male mice can lead to significantly increased levels of DNA damage in meiotic germ cells. $M L H 1$ is a DNA mismatch repair gene, and MLH1 foci at the pachytene phase were used to distinguish the sites of exchange. Homologous recombination is the key to meiotic function. MLH1 in combination with the DNA damage marker $\gamma \mathrm{H} 2 \mathrm{AX}$ reveals variations in MLH1 foci in 
chromosomes that lead to meiosis failure. ${ }^{54}$ To verify this phenomenon, pachytene analysis at metaphase I was carried out to verify the recombination status. Recombination is regulated by crossover interference, a mechanism that ensures at least one exchange per chromosome pair and controls the proximity of multiple exchanges on a given chromosome. Thus, the average number of MLH1 foci per cell and the frequency of chromosomes with zero, one, two, or three MLH1 foci were analyzed in germ cells (Figure 7). The pachytene analysis showed an increase in the average number of MLH1 foci per cell and a disturbed exchange frequency of chromosomes with zero, one, two, or three MLH1 foci in germ cells at PND42 (Figure 7D and E). No significant changes were observed at PND28 and PND60. Variation in the expression of $M L H 1$ may explain the observed variation in foci intensity. However, as shown in Figure S1, the expression of $M L H 1$ was not significantly changed. In a pilot study, we investigated the effects of subcutaneous injection of AgNPs on the reproductive system of male mice. AgNPs caused shrinkage of the convoluted tubules in mice at PND28 and PND42, and the tissue damage was repaired by PND60 and PND100. Sperm were affected by the AgNPs throughout the 100-day study period. We did not find a significant change in the expression of $M L H 1$ genes (Figure S1) and MLH1 foci at the pachytene chromosome, and only the MLH1 foci exchange frequency was disturbed at PND42. Although our study showed that AgNPs have minor effects on the male reproductive system in mice, it is possible that these materials may accumulate in high quantities over a longer period and may also have adverse effects on male fertility. A study conducted by Garcia et $\mathrm{l}^{55}$ showed that AgNPs intravenously injected into males resulted in no changes in body weight, testis weight, sperm concentration, and motility and fertility indices; however, LC function was affected, resulting in increased testicular and serum testosterone levels. ${ }^{56}$ In another study, with the exception of one high dose, the administration of AgNPs resulted in a dose-dependent decrease in the body weight of rats, and dose-dependent changes in alkaline phosphatase activity and cholesterolemia. ${ }^{57} \mathrm{Kim}$ et al evaluated the oral toxicity of AgNPs over 28 days in Sprague Dawley rats, and they observed no changes in body weight or organ weight. ${ }^{58}$ Li et al administered AgNPs via intravenous injection in mice and showed that the AgNPs reached the bone marrow and liver, and induced cytotoxicity in reticulocytes
A

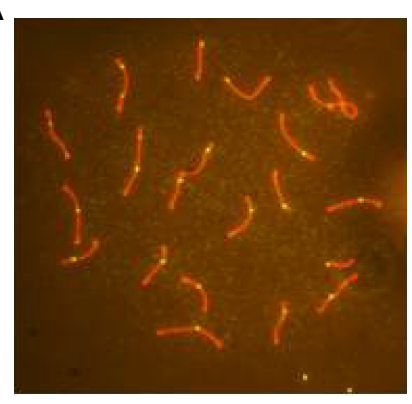

D

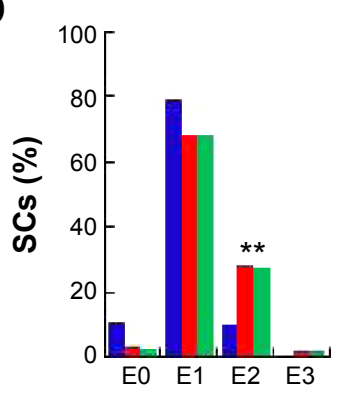

B
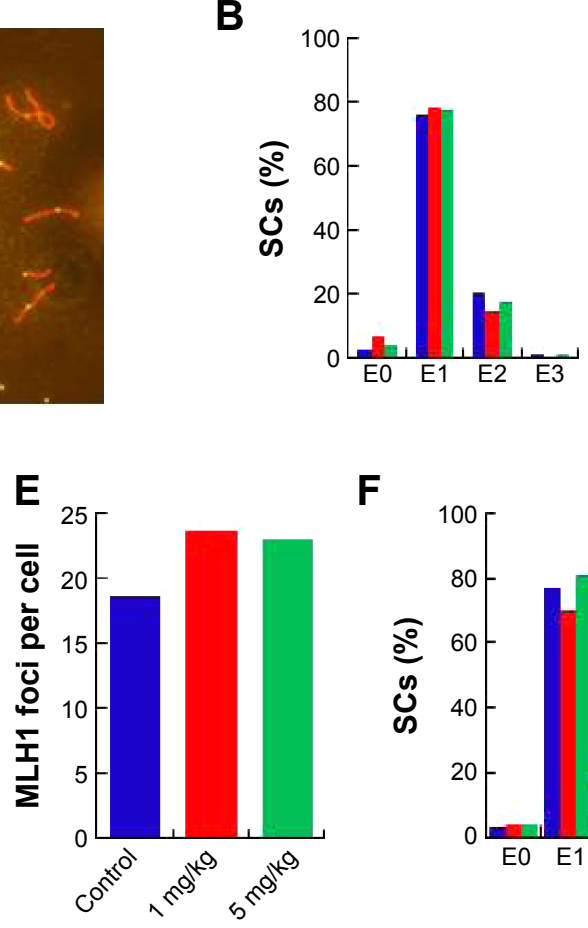

F

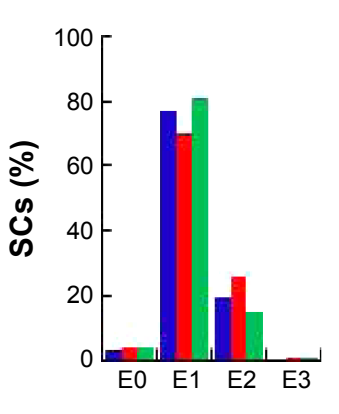

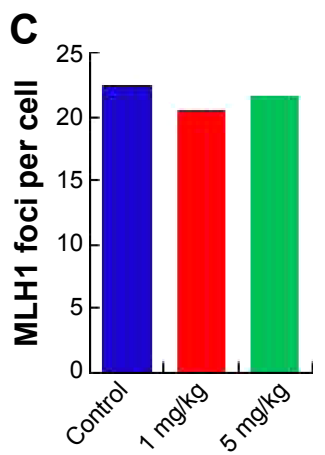

G

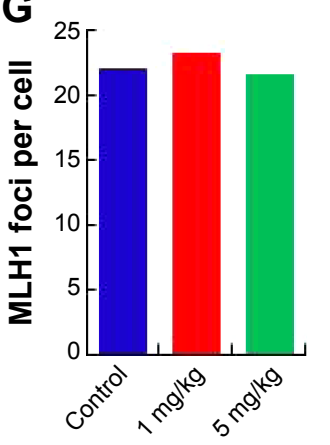

Control $\quad 1 \mathrm{mg} / \mathrm{kg} \quad \square \mathrm{mg} / \mathrm{kg}$

Figure 7 Pachytene analysis of germ cells from silver nanoparticles-exposed males and controls.

Notes: (A) Representative immunostaining image of MLHI in pachytene spermatocytes. Double immunostaining with antibodies against SYCP3 (red) and MLHI (green) for detection of the synaptonemal complex and sites of recombination. (B), (D), and (F) Distribution of MLHI foci. The proportion of Sertoli cells with zero, one, two, or three MLHI foci (exchange) in pachytene cells from silver nanoparticles-exposed males at postnatal day PND28, PND42, and PND60. (C), (E), and (G). MLHI foci per cell from silver nanoparticles-exposed males at PND28, PND42, and PND60. $* * P>0.01$.

Abbreviation: SCs, Sertoli cells. 
and oxidative DNA damage in the liver. ${ }^{59}$ Another report showed that there was a significant decrease $(P<0.05)$ in the body weight of mice in all of the AgNPs-treated groups, and the AgNPs also damaged epithelial cell microvilli as well as the intestinal glands. ${ }^{60}$
Effects of AgNPs on gene expression in the mouse testes

Gene expression in the mouse testes in response to AgNPs was assessed using real-time PCR. Total RNA from the testis was isolated for RT-PCR analysis (Figures 8, S1, and S2).

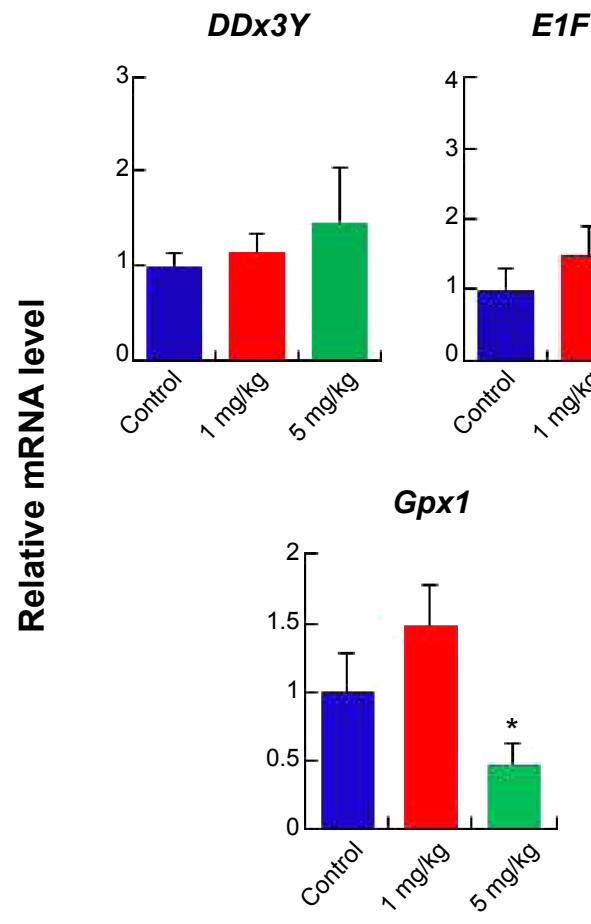

E1F1AY
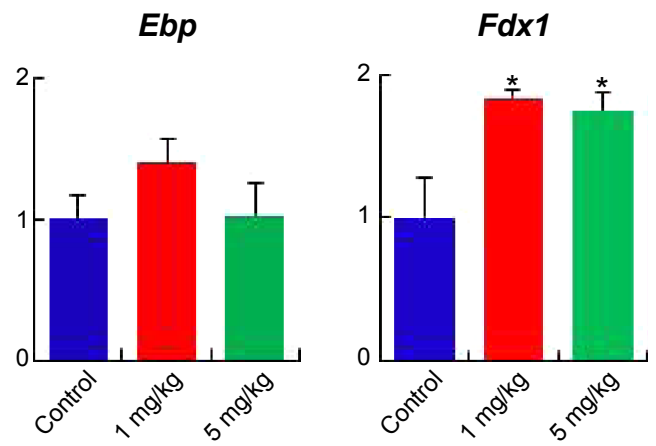

\section{Gpx1}

Gsta4

$\operatorname{Prdx2}$

Cyp17a1

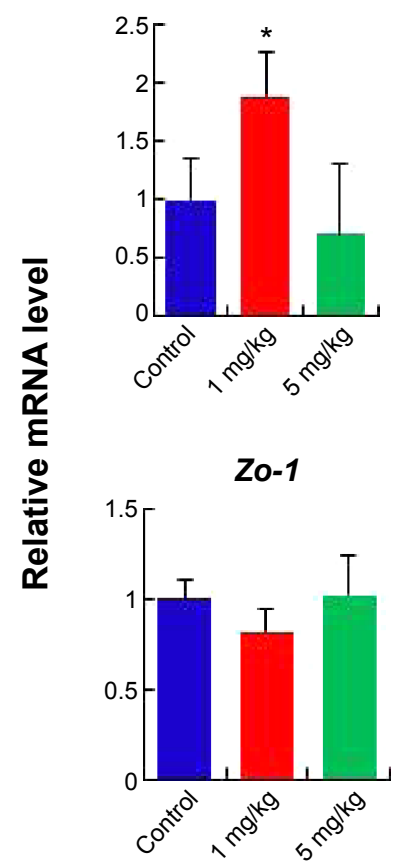

Cyp19a1

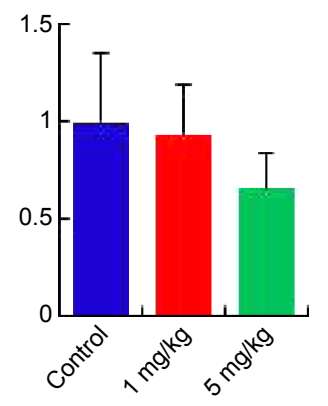

Occludin

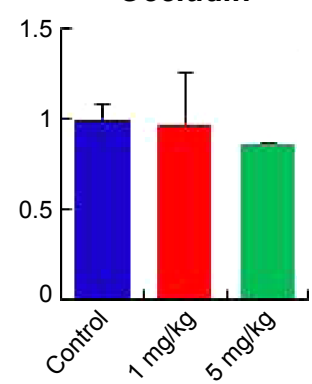

StAR

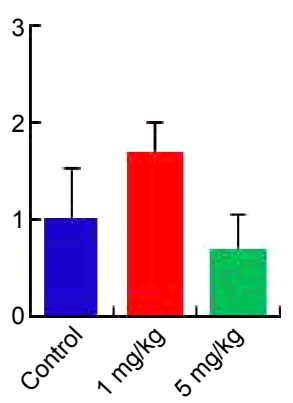

Claudin-11

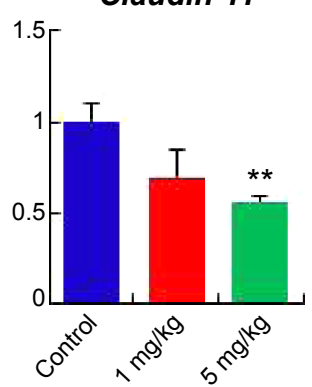

Amh

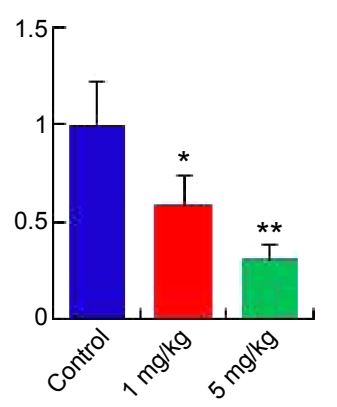

Cx43

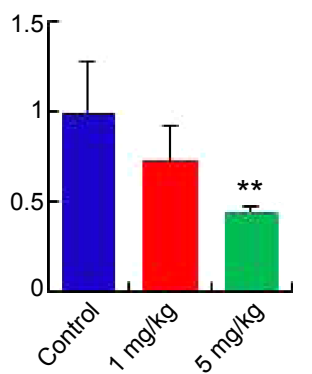

Figure 8 mRNA expression levels of specific genes at postnatal day 28 .

Notes: The results are presented as mean \pm SD. *Indicates significance at $P<0.05$; **indicates significance at $P<0.01$.

Abbreviation: SD, standard deviation. 
The DDx3Y and E1F1AY genes, which are associated with sperm quality, were up-regulated in the AgNPs-treated group at PND28 and PND42. However, these two genes were downregulated at PND60 (Figure S2). In addition, the expression levels of the $F d x 1$, Gsta4, and $\operatorname{Prdx} 2$ genes were down-regulated at PND60 (Figure S2). We next examined the transcription levels of enzymes involved in cholesterol, testosterone, and estradiol biosynthesis using fragments of the whole testes. The Cyp19al gene is a steroid hormone synthesis gene encoding CYP19a1, which is the key steroidogenic enzyme responsible for the conversion of androgen stoestrogens. ${ }^{61}$ The expression of Cyp 19al was induced in the $5 \mathrm{mg} / \mathrm{kg}$ AgNPs-treated group at PND28 and PND42; however, the expression recovered at PND60. Similarly, a previous gene expression analysis revealed that Cyp1 1al mRNA was significantly up-regulated in AgNPs-treated animals. ${ }^{55}$ The anti-Mullerian hormone (AMH) is a homodimeric glycoprotein of the transforming growth factor- $\beta$ superfamily, and is synthesized by SCs in the mouse testis. ${ }^{55}$ In this study, the expression of $\mathrm{Amh}$ was significantly reduced in the treated group at PND28, and then recovered at PND42 and PND60. The expression pattern of the Cx43 and Claudin-11 genes was similar to that of the Amh gene.

\section{Conclusion}

To address the impact of AgNPs on testis development in neonatal mice, we synthesized AgNPs using B. funiculus as a reducing and stabilizing agents. This is very simple, green approach, non-toxic, and biocompatible. As prepared AgNPs were characterized using various analytical techniques. The synthesized AgNPs shows with an average size of $15 \mathrm{~nm}$. The results showed that the quantity and quality of sperm were significantly affected by the synthesized AgNPs. The results of RT-PCR indicated that the E1F1AY, Gsta4, and FdxI genes were up-regulated, and the $A m h, C x 43$, and Claudin- 11 genes were down-regulated in response to AgNP exposure on PND28. Our studies indicate that AgNPs induces detrimental effects in neonatal mice, particularly spermatogenesis and the quality of sperm. In addition, these data could provide significant knowledge in the field of toxicological effect of AgNPs in animals. Moreover, this study can provide important information for the development of safe and non-toxic nanomaterials to animals and human as well. However, further studies are urgently needed on the reproductive toxicity of these nanomaterials, particularly following long-term exposure.

\section{Acknowledgments}

This work was supported by the KU-Research Professor Program of Konkuk University. Dr Sangiliyandi Gurunathan was supported by a Konkuk University KU-Full-time Professorship. This work was supported by the Woo JangChoon project (PJ007849).

\section{Disclosure}

The authors report no conflicts of interest in this work.

\section{References}

1. National Nanotechnology Infrastructure Network. Serving Nanoscale Science, Engineering \& Technology. Available from: http://www.nnin. org/education-training. Accessed February 18, 2013.

2. Estelrich J, Sánchez-Martín MJ, Busquets MA. Nanoparticles in magnetic resonance imaging: from simple to dual contrast agents. Int J Nanomed. 2015;10:1727-1741.

3. Polak P, Shefi O. Nanometric agents in the service of neuroscience. Manipulation of neuronal growth and activity using nanoparticles. Nanomedicine. 2015;11(6):1467-1479.

4. Toporkiewicz M, Meissner J, Matusewicz L, Czogalla A, Sikorski AF Toward a magic or imaginary bullet? Ligands for drug targeting to cancer cells: principles, hopes, and challenges. Int J Nanomed. 2015;10: 1399-1414.

5. Maillard JY, Hartemann P. Silver as an antimicrobial: facts and gaps in knowledge. Crit Rev Microbiol. 2013;39:373-383.

6. Zhang L, Chen L, Chen LW, Zhu G. A facile synthesis of flower-shaped $\mathrm{TiO}_{2} / \mathrm{Ag}$ microspheres and their application in photocatalysts. RSC $A d v$. 2014;4:54463-54468.

7. Markowska K, Grudniak AM, Wolska KI. Silver nanoparticles as an alternative strategy against bacterial biofilms. Acta Biochim Pol. 2013 60:523-530

8. Zhang L. Self-assembly Ag nanoparticle monolayer film as SERS Substrate for pesticide detection. Appl Surf Sci. 2013;270:292-294.

9. Lara HH, Garza-Treviño EN, Ixtepan-Turrent L, Singh DK. Silver nanoparticles are broad-spectrum bactericidal and virucidal compounds. J Nanobiotech. 2011;9:30.

10. Yamanaka M, Hara K, Kudo J. Bactericidal actions of a silver ion solution on Escherichia coli, studied by energy-filtering transmission electron microscopy and proteomic analysis. Appl Environ Microbiol. 2005;71:7589-7593.

11. Wei L, Lu J, Xu H, Patel A, Chen ZS, Chen G. Silver nanoparticles: synthesis, properties, and therapeutic applications. Drug Discov Today. 2015;20:595-601.

12. Dos Santos CA, Seckler MM, Ingle AP, et al. Silver nanoparticles: therapeutical uses, toxicity, and safety issues. J Pharm Sci. 2014;103:1931-1944.

13. Prabhu S, Eldho KP. Silver nanoparticles: mechanism of antimicrobial action, synthesis, medical applications, and toxicity effects. Int Nano Lett. 2012;2:32

14. Wei L, Lu J, Xu HZ, Patel A, Chen Z-S, Chen G. Silver nanoparticles: synthesis, properties, and therapeutic applications. Drug Discov Today. 2015;20(5):595-601. http://dx.doi.org/10.1016/j.drudis

15. Mathias FT, Romano RM, Kizys MM, et al. Daily exposure to silver nanoparticles during prepubertal development decreases adult sperm and reproductive parameters. Nanotoxicology. 2015;9:64-70.

16. Lee YH, Cheng FY, Chiu HW, et al. Cytotoxicity, oxidative stress, apoptosis and the autophagic effects of silver nanoparticles in mouse embryonic fibroblasts. Biomaterials. 2014;35:4706-4715

17. Miethling-Graff R, Rumpker R, Richter M, et al. Exposure to silver nanoparticles induces size- and dose-dependent oxidative stress and cytotoxicity inhumancolon carcinomacells. Toxicol In Vitro. 2014;28:1280-1289.

18. Gliga AR, Skoglund S, Wallinder IO, Fadeel B, Karlsson HL. Size-dependent cytotoxicity of silver nanoparticles inhumanlungcells: the role of cellular uptake, agglomeration and Ag release. Part Fibre Toxicol. 2014;11:11.

19. Tang J, Xiong L, Wang S, et al. Distribution, translocation and accumulation of silver nanoparticles in rats. J Nanosci Nanotechnol. 2009; 9:4924-4932. 
20. Hyun JS, Lee BS, Ryu HY, Sung JH, Chung KH, Yu IJ. Effects of repeated silver nanoparticles exposure on the histological structure and mucins of nasal respiratory mucosa in rats. Toxicol Lett. 2008;182:24-28.

21. Rahman MF, Wang J, Patterson TA, et al. Expression of genes related to oxidative stress in the mouse brain after exposure to silver-25 nanoparticles. Toxicol Lett. 2009;187:15-21.

22. Choi JE, Kim S, Ahn JH, et al. Induction of oxidative stress and apoptosis by silver nanoparticles in the liver of adult zebrafish. Aquat Toxicol. 2010;100:151-159.

23. Shi J, Sun X, Lin Y, et al. Endothelial cell injury and dysfunction induced by silver nanoparticles through oxidative stress via IKK/NF- $\mathrm{\kappa B}$ pathways. Biomaterials. 2014;35:6657-6666.

24. Satapathy SR, Mohapatra P, Preet R, et al. Silver-based nanoparticles induce apoptosis in human colon cancer cells mediated through $\mathrm{p} 53$. Nanomedicine (Lond). 2013;8:1307-1322.

25. Piao MJ, Kang KA, Lee IK, et al. Silver nanoparticles induce oxidative cell damage in human liver cells through inhibition of reduced glutathione and induction of mitochondria-involved apoptosis. Toxicol Lett. 2011;201:92-100.

26. Tran QH, Nguyen VQ, Le AT. Silver nanoparticles: synthesis, properties, toxicology, applications and perspectives. Adv Nat Sci: Nanosci Nanotechnol. 2013;4:033001.

27. Gnanadhas DP, Ben Thomas M, Thomas R, Raichur AM, Chakravortty D. Interaction of silver nanoparticles with serum proteins affects their antimicrobial activity in vivo. Antimicrob Agents Chemother. 2013;57: 4945-4955.

28. Shenashen MA, El-Safty SA, Elshehy EA. Synthesis, morphological control, and properties of silver nanoparticles in potential applications. Part Part Syst Charact. 2014;31:293-316.

29. Sintubin L, Verstraete W, Boon N. Biologically produced nanosilver: current state and future perspectives. Biotechnol Bioeng. 2012;109: 2422-2436.

30. Singh R, Shedbalkar UU, Wadhwani SA, Chopade BA. Bacteriagenic silver nanoparticles: synthesis, mechanism, and applications. Appl Microbiol Biotechnol. 2015;99:4579-4593.

31. Mallmann EJ, Cunha FA, Castro BN, Maciel AM, Menezes EA, Fechine PB. Antifungal activity of silver nanoparticles obtained by green synthesis. Rev Inst Med Trop Sao Paulo. 2015;57:165-167.

32. Gou Y, Zhang F, Zhu X, Li X. Biosynthesis and characterization of silver nanoparticles using Sphingomonas paucimobilis sp. BDS1. IET Nanobiotechnol. 2015;9:53-57.

33. Kalimuthu K, Babu RS, Venkataraman D, Bilal M, Gurunathan S. Biosynthesis of silver nanocrystals by Bacillus licheniformis. Colloids Surf B Biointerfaces. 2008;65:150-153.

34. Kalishwaralal K, Deepak V, Ram Kumar Pandian S, et al. Biosynthesis of silver and gold nanoparticles using Brevibacterium casei. Colloids Surf B Biointerfaces. 2010;77:257-262.

35. Gurunathan S, Kalishwaralal K, Vaidyanathan R, et al. Biosynthesis, purification and characterization of silvernanoparticles using Escherichia coli. Colloids Surf B Biointerfaces. 2009;74:328-335.

36. Zhang XF, Choi YJ, Han JW, et al. Differential nanoreprotoxicity of silver nanoparticles in male somatic cells and spermatogonial stem cells. Int J Nanomed. 2015;10:1335-1357.

37. Zhang XF, Zhang T, Wang L, et al. Effects of diethylhexyl phthalate (DEHP) given neonatally on spermatogenesis of mice. Mol Biol Rep. 2013;40:6509-6517.

38. Taylor U, Barchanski A, Kues W, Barcikowski S, Rath D. Impact of metal nanoparticles on germ cell viability and functionality. Reprod Domest Anim. 2012;47(4):359-368.

39. Sastry CS, Srinivas Y, Rao PV. Assay of cisapride in pharmaceutical formulations by extraction spectrophotometry. Talanta. 1997;44(4):517-526.

40. Shankar SS, Joshi H, Pasricha R, Pavaskar NR, Mandale AB, Sastry M. A low-temperature, soft chemistry method for the synthesis of zirconia nanoparticles in thermally evaporated fatty amine thin films. $J$ Colloid Interface Sci. 2004;269(1):126-130.
41. Kumar VG, Gokavarapu SD, Rajeswari A, et al. Facile green synthesis of gold nanoparticles using leaf extract of antidiabetic potent Cassia auriculata. Colloids Surf B Biointerfaces. 2011;87:159-163.

42. Sankaran M, Vadivel A, Krishnamoorthy D, Mani K. Intracellular biosynthesis and antibacterial activity of silver nanoparticles using edible mushrooms. Not Sci Biol. 2012;4(4):55-61.

43. Sahu SC, Zheng J, Yourick JJ, Sprando RL, Gao X. Toxicogenomic responses of human liver HepG2 cells to silver nanoparticles. $J$ Appl Toxicol. 2015; doi:10.1002/ jat.3170.

44. Gurunathan S, Jeong JK, Han JW, Zhang XF, Park JH, Kim JH. Multidimensional effects of biologically synthesized silver nanoparticles in Helicobacter pylori, Helicobacter felis, and human lung (L132) and lung carcinoma A549 cells. Nanoscale Res Lett. 2015;10:35. doi:10.1186/ s11671-015-0747-0.

45. Huang CL, Hsiao IL, Lin HC, Wang CF, Huang YJ, Chuang CY. Silver nanoparticles affect on gene expression of inflammatory and neurodegenerative responses in mouse brain neural cells. Environ Res. 2015; 136:253-263.

46. Feng X, Chen A, Zhang Y, Wang J, Shao L, Wei L. Application of dental nanomaterials: potential toxicity to the central nervous system. Int J Nanomed. 2015;10:3547-3565.

47. Thakur M, Gupta H, Singh D, et al. Histopathological and ultra structural effects of nanoparticles on rat testis following 90 days (Chronic study) of repeated oral administration. J Nanobiotechnology. 2014;12(1):42.

48. Zhao X, Sheng L, Wang L, et al. Mechanisms of nanosized titanium dioxide-induced testicular oxidative stress and apoptosis in male mice. Part Fibre Toxicol. 2014;11(1):47.

49. Lankveld DP, Oomen AG, Krystek P, et al. The kinetics of the tissue distribution of silver nanoparticles of different sizes. Biomaterials. 2010; 31:8350-8361.

50. Park EJ, Bae E, Yi J, et al. Repeated-dose toxicity and inflammatory responses in mice by oral administration of silver nanoparticles. Environ Toxicol Pharmacol. 2010;30(2):162-168.

51. Braydich-Stolle LK, Lucas B, Schrand A, et al. Silver nanoparticles disrupt GDNF/Fyn kinase signaling in spermatogonial stem cells. Toxicol Sci. 2010;116(2):577-589.

52. Braydich-Stolle L, Hussain S, Schlager JJ, Hofmann MC. In vitro cytotoxicity of nanoparticles in mammalian germline stem cells. Toxicol Sci. 2005;88(2):412-419.

53. Gromadzka-Ostrowska J, Dziendzikowska K, Lankoff A, et al. Silver nanoparticles effects on epididymal sperm in rats. Toxicol Lett. 2012; 214(3):251-258.

54. De Vries M, Ramos L, De Boer P. Immunofluorescent characterization of meiotic recombination in human males with variable spermatogenesis. Andrology. 2013;1:262-273.

55. Garcia TX, Costa GM, França LR, Hofmann MC. Sub-acute intravenous administration of silver nanoparticles in male mice alters Leydig cell function and testosterone levels. Reprod Toxicol. 2014;45:59-70.

56. Dresser DW, Guerrier D. Candidate Sertoli cell specific promoter element for a TGF beta family member (Amh) and a 3' UTR enhancer/ repressor for the same gene. Gene. 2005;363:159-165.

57. Kim YS, Song MY, Park JD, et al. Subchronic oral toxicity of silver nanoparticles. Part Fibre Toxicol. 2010;7:20.

58. Kim YS, Kim JS, Cho HS, et al. Twenty-eight day oral toxicity, genotoxicity, and gender-related tissue distribution of silver nanoparticles in Sprague-Dawley rats. Inhal Toxicol. 2008;20:575-583.

59. Li Y, Bhalli JA, Ding W, et al. Cytotoxicity and genotoxicity assessment of silver nanoparticles in mouse. Nanotoxicology. 2014;8:36-45.

60. Shahare B, Yashpal M. Toxic effects of repeated oral exposure of silver nanoparticles on small intestine mucosa of mice. Toxicol Mech Methods. 2013;23:161-167.

61. Al-Bader M, Kilarkaje N. Effects of bleomycin, etoposide and cisplatin treatment on Leydig cell structure and transcription of steroidogenic enzymes in rat testis. Eur J Pharmacol. 2015;747:150-159. 


\section{Supplementary materials}

A

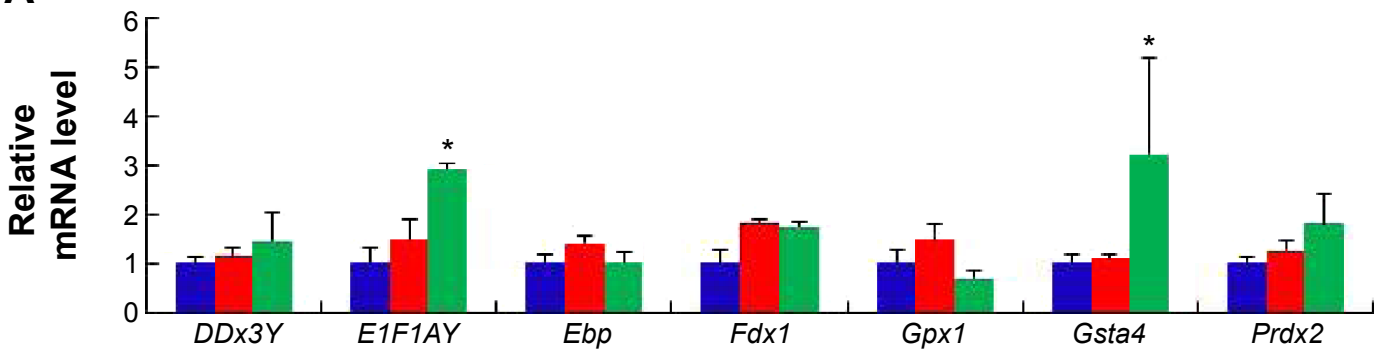

B
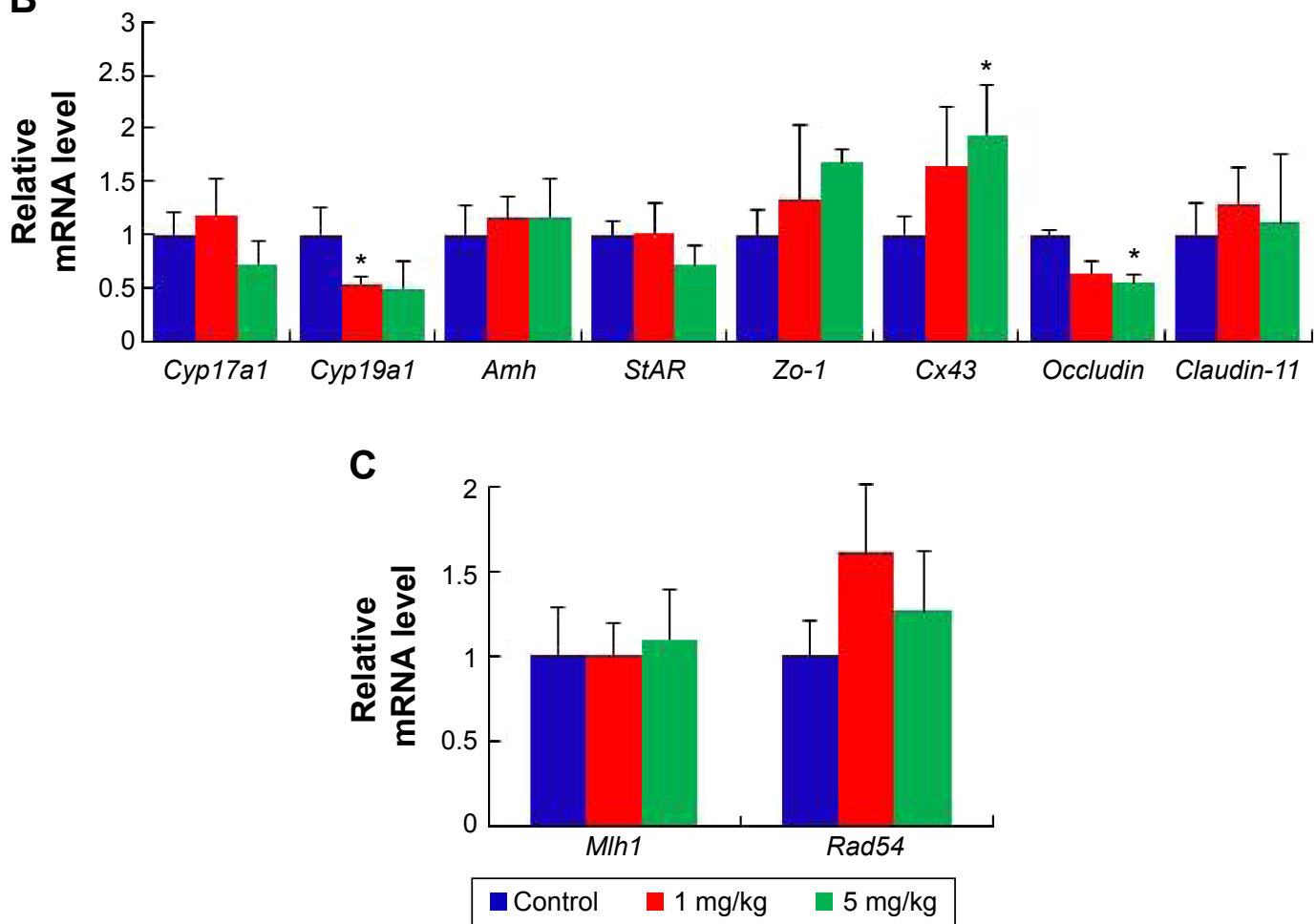

Figure SI mRNA expression levels of specific genes at postnatal day 42.

Notes: (A) The relative expression of the genes of germ development. (B) The relative expression of the specific genes in LCs and SCs. (C) The relative expression of the genes relative to chromosome repair. The results are presented as the mean \pm SD. *Indicates significance of $P<0.05$.

Abbreviations: LCs, Leydig cells; SCs, Sertoli cells; SD, standard deviation. 

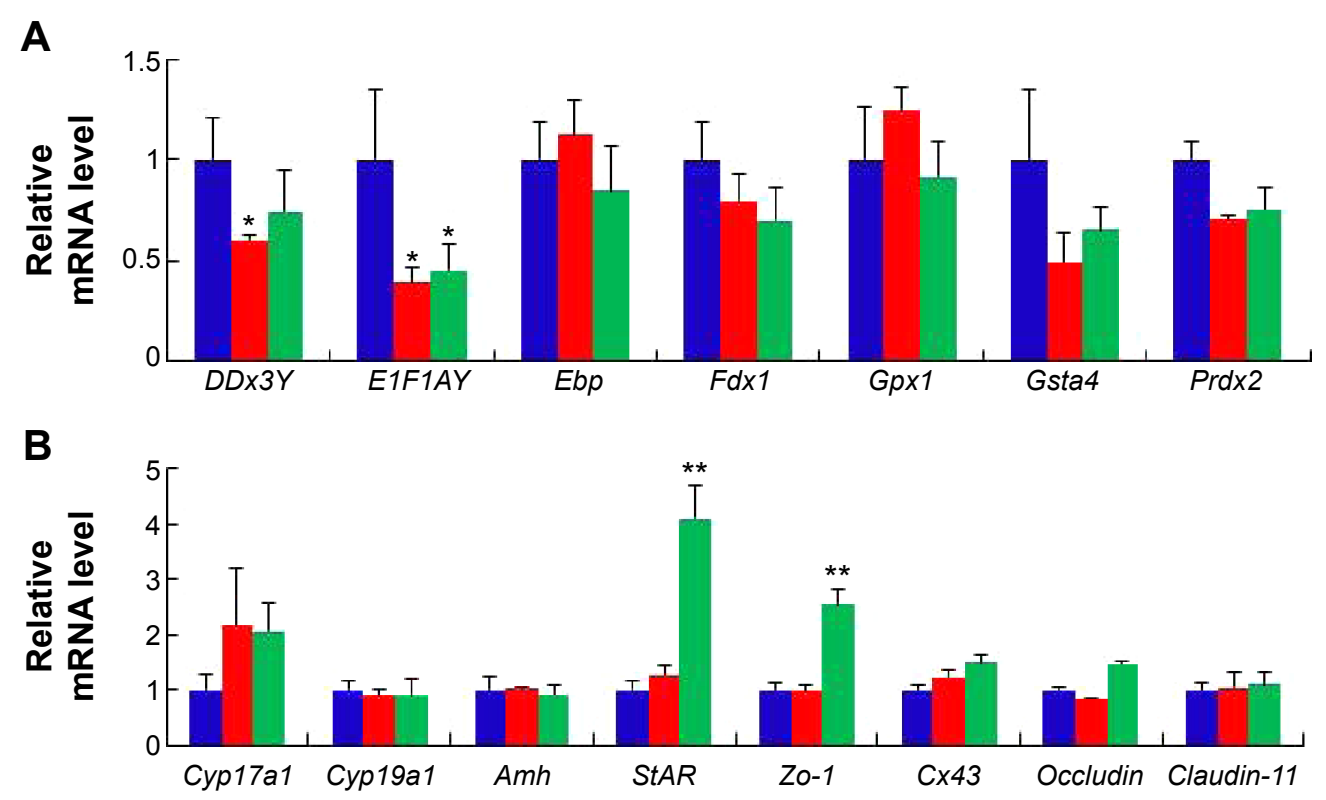

- Control $\square 1 \mathrm{mg} / \mathrm{kg} \quad \square \mathrm{mg} / \mathrm{kg}$

Figure S2 mRNA expression of specific genes at postnatal day 60 .

Notes: (A) The relative expression of the genes of germ development. (B) The relative expression of the specific genes in LCs and SCs. The results are presented as the mean \pm SD. *Indicates significance of $P<0.05$; **indicates significance of $P<0.01$.

Abbreviations: LCs, leydig cells; SCs, sertoli cells; SD, standard deviation.

\section{Publish your work in this journal}

The International Journal of Nanomedicine is an international, peerreviewed journal focusing on the application of nanotechnology in diagnostics, therapeutics, and drug delivery systems throughout the biomedical field. This journal is indexed on PubMed Central, MedLine, CAS, SciSearch ${ }^{\circledR}$, Current Contents ${ }^{\circledR} /$ Clinical Medicine,
Journal Citation Reports/Science Edition, EMBase, Scopus and the Elsevier Bibliographic databases. The manuscript management system is completely online and includes a very quick and fair peer-review system, which is all easy to use. Visit http://www.dovepress.com/ testimonials.php to read real quotes from published authors. 